\title{
PENGARUH POPULASI IKAN NILA TERHADAP KETERSEDIAAN HARA DAN PERTUMBUHAN TANAMAN PADI SAWAH PADA SISTEM MINA PADI DI DUSUN BIRU, DESA TRIHANGGO, KECAMATAN GAMPING, KABUPATEN SLEMAN, D.I YOGYAKARTA
}

\section{(EFFECT OF TILAPIA FISH POPULATION TO SOIL NUTRIENT AVAILIBILITY AND PADDY GROWTH ON PADDY FISH CULTURE IN BIRU, TRIHANGGO, GAMPING, SLEMAN, SEPECIAL REGION OF YOGYAKARTA)}

\author{
Rinetta Andyka Puri ${ }^{1)}$ Miseri Roeslan Afany ${ }^{\left.2)^{*}\right)}$, dan Lelanti Peniwiratri ${ }^{2)}$ \\ ${ }^{1)}$ Prodi Agroteknologi, Universitas Pembangunan Nasional Veteran Yogyakarta \\ ${ }^{2}$ Prodi Ilmu Tanah, Universitas Pembangunan Nasional Veteran Yogyakarta \\ ${ }^{*}$ Corresponding author E - mail: miseriroeslan.afany@yahoo.com
}

\begin{abstract}
The food necesity is continues to increase making paddy as a top priority for increasing productivity results. Many ways are making to increase paddy growth without chemical approaching, one of them is paddy fish culture. The objective of this research is to measure effect of fish population on paddy fish culture to soil nutrient availibility and paddy growth in Dusun Biru. The research use randomized complete block design (RCBD), consist of 4 treatments. First treatment as $\mathrm{P} 0$ is a convensional paddy field (control), the second treatment as $\mathrm{P} 1$ is paddy fish culture with 22 fishes population per square, third treatment as P2 is paddy fish culture with 33 fishes population per square, last treatment as P3 is paddy fish culture with 44 fishes population per square. Each treatment repeated 4 times and resulting 16 samples. Paramenters of the research are $\mathrm{pH} \mathrm{H}_{2} \mathrm{O}, \mathrm{pH} \mathrm{KCl}, \mathrm{Eh}, \mathrm{Fe}, \mathrm{Mn}, \mathrm{C}$ organics, $\mathrm{N}$ availbility, $\mathrm{P}$ avalibility and $\mathrm{K}$ availibility, then parameters for plants height, number of tillers, wet weight and dry weight. To know treatment effect by analysis of variance (ANOVA) continued by Duncan Multiple Range Test (DMRT) on $5 \%$ level. Result of research shows number of fish population on paddy fish culture does not show significan increase on $\mathrm{pH}, \mathrm{Eh}, \mathrm{C}$ - organic, $\mathrm{N}$ availibility, $\mathrm{P}$ availibility, $\mathrm{K}$ availibility, $\mathrm{Fe}, \mathrm{Mn}$. Instead significan to increase plants height, number of tiller, wet weight and dry weight on plants and wet weight of fishes.
\end{abstract}

Keywords: tilapia fish, soil nutrient, paddy fish farming, population.

\begin{abstract}
ABSTRAK
Kebutuhan pangan yang terus meningkat menjadikan padi sebagai prioritas utama untuk meningkatkan hasil produktivitasnya. Upaya yang dilakukan untuk meningkatkan pertumbuhan padi tanpa penggunaan pupuk kimia yaitu dengan menerapkan sistem mina padi. Penelitian ini dilakukan untuk mengetahui pengaruh populasi ikan pada sistem mina padi terhadap ketersediaan hara tanah dan pertumbuhan padi sawah di Dusun Biru. Penelitian ini menggunakan Rancangan Acak Kelompok Lengkap (RAKL) yang terdiri dari 4 perlakuan. Perlakuan tersebut terdiri dari P0 = Lahan sawah konvensional (kontrol), P1 = Lahan sawah mina padi dengan kepadatan ikan 22 ekor/petak, P2 = Lahan sawah mina padi dengan kepadatan ikan 33 ekor/petak, P3 = Lahan sawah mina padi dengan kepadatan ikan 44 ekor/petak. Masing - masing perlakuan diulang 4 kali, sehingga diperoleh 16 sampel. Parameter penelitian untuk tanah adalah $\mathrm{pH} \mathrm{H} 2 \mathrm{O}, \mathrm{pH} \mathrm{KCl}$,
\end{abstract}


$\mathrm{Eh}, \mathrm{Fe}, \mathrm{Mn}$, bahan organik, $\mathrm{N}$ tersedia, $\mathrm{P}$ tersedia, dan $\mathrm{K}$ tersedia, sedangkan untuk tanaman adalah tinggi tanaman, jumlah anakan, berat segar tanaman, dan berat kering tanaman. Untuk mengetahui pengaruh perlakuan dengan sidik ragam (ANOVA) dengan dilanjutkan menggunakan Duncan Multiple Range Test (DMRT) pada taraf 5\%. Hasil penelitian menunjukkan bahwa jumlah populasi ikan pada sistem mina padi tidak berpengaruh nyata dalam meningkatkan $\mathrm{pH}$, Eh, $\mathrm{C}$ - organic, $\mathrm{N}$ tersedia, $\mathrm{P}$ tersedia, $\mathrm{K}$ tersedia, Fe, Mn. Tetapi berpengaruh nyata terhadap meningkatkan tinggi tanaman, jumlah anakan, berat segar tanaman, berat kering tanaman, dan berat segar ikan.

Kata Kunci: ikan nila, ketersediaan hara, mina padi, populasi

\section{PENDAHULUAN}

Padi merupakan makanan pokok bagi sebagian besar masyarakat Indonesia. Permintaan komoditas padi tercatat dari tahun ke tahun terus melonjak sejalan dengan bertambahnya jumlah penduduk. Kebutuhan pangan yang terus meningkat seiring dengan meningkatnya jumlah penduduk di Indonesia menjadikan padi sebagai prioritas utama untuk ditingkatkan hasil produktivitasnya. Banyak upaya yang dilakukan untuk meningkatkan pertumbuhan, salah satunya dengan penggunaan pupuk kimia. Namun penggunaan pupuk kimia yang berlebih dan terus menerus dapat mengganggu keseimbangan lingkungan. Upaya yang dilakukan untuk mengurangi penggunaan pupuk kimia ini yaitu dengan menerapkan sistem mina padi.

Mina padi merupakan salah satu bentuk tumpang sari pemeliharaan padi di sawah bersama-sama dengan pemeliharaan ikan. Penggunaan sistem mina padi dilakukan untuk upaya memanfaatkan lahan sehingga lahan dapat digunakan secara optimal dan efisien. Sistem ini memanfaatkan kotoran ikan untuk meningkatkan kesuburan tanah dengan memperbaiki sifat fisik, kimia, dan biologi tanah. Asam amino yang terdapat pada protein pakan ikan dan amoniak yang berasal dari kotoran ikan berpotensi menjadi unsur nitrogen yang dibutuhkan tanaman. Tanah - tanah pada sistem persawahan dengan penggenangan akan mendorong perubahan elektrokimia yang mempengaruhi penyediaan dan pengambilan hara. Perubahan sifat - sifat kimia tersebut antara lain terjadinya perubahan potensial redoks $(\mathrm{Eh})$ dan keasaman tanah $(\mathrm{pH})$ yang merupakan dua faktor utama yang saling berkaitan dalam mempengaruhi kelarutan dan ketersediaan hara di dalam tanah serta berpengaruh terhadap pertumbuhan dan produksi padi (Ciyo, 2008).

Lokasi yang dinilai memiliki potensi keberhasilan untuk menerapkan budidaya padi dengan sistem mina padi adalah di Dusun Biru, Desa Trihanggo, Kecamatan Gamping, Kabupaten Sleman. Di lokasi tersebut banyak lahan yang digunakan untuk budidaya sawah konvensional. Dilokasi tersebut penanaman padi dilakukan terus menerus sepanjang tahun tanpa ada pergiliran tanaman. Dengan persediaan air irigasi yang lancar dan tersedia sepanjang tahun serta lokasi terhindar dari banjir dan pencemaran maka lokasi tersebut memiliki potensi untuk dilakukan budidaya padi dengan sistem mina padi. Padi varietas rojo lele dinilai cocok untuk ditanam dengan sistem mina padi karena memiliki bentuk tanaman tegak, berakar kuat dan memiliki tingkat kerebahan yang sedang. Ikan nila cocok digunakan pada sawah mina padi karena ikan nila dinilai mudah hidup dan memiliki nilai ekonomis. Dengan diaplikasikannya sistem mina padi di lokasi tersebut diharapkan meningkatkan pendapatan petani di daerah. Penelitian ini bertujuan untuk mengetahui pengaruh jumlah ikan pada sistem mina padi sawah terhadap ketersediaan hara tanah dan pertumbuhan padi sawah di dusun Biru, desa Trihanggo, kecamatan Gamping, kabupaten Sleman. 


\section{METODE PENELITIAN}

Penelitian dilaksanakan di Biru, Desa Trihanggo, Kecamatan Gamping, Kabupaten Sleman. Analisis dilakukan di Laboratorium Program Studi Ilmu Tanah Fakultas Pertanian UPN "Veteran" Yogyakarta. Penelitian ini menggunakan Rancangan Acak Kelompok Lengkap (RAKL) yang terdiri dari 4 perlakuan dengan 4 kali ulangan. Perlakuan tersebut antara lain (Sudiarta, 2016) P0 = Lahan sawah konvensional (kontrol), P1 = Lahan sawah mina padi dengan kepadatan ikan 22 ekor/ petak, P2 = Lahan sawah mina padi dengan kepadatan ikan 33 ekor/ petak, P3 = Lahan sawah mina padi dengan kepadatan ikan 44 ekor/ petak.

Ukuran petak yang digunakan untuk masing - masing perlakuan adalah $2 \mathrm{~m} \times 2 \mathrm{~m}$, dengan lebar permukaan atas pematang sawah $30 \mathrm{~cm}$ dan ketinggian $40-50 \mathrm{~cm}$ parit dibuat dengan ukuran lebar $20 \mathrm{~cm}$ dengan kedalaman 15-20 $\mathrm{cm}$ dari permukaan sawah. Kemudian dibuat pintu pemasukan menggunakan pipa berdiameter $3 \mathrm{~cm}$ dan pintu pengeluaran air menggunakan pipa berdiameter $5 \mathrm{~cm}$. untuk setiap pintu dibuat daun pintu yang mampu menahan air untuk tidak masuk/keluar petakan sesuai kebutuhan. Sedangkan untuk mengatasi air limpahan dipasang pipa paralon pada pematang sawah. Setelah selesai petakan diisi air setinggi $5 \mathrm{~cm}$ dari permukaan tanah sawah (Anonim, 1991).

Penanaman padi menggunakan bibit padi varietas rojo lele. Jarak tanam yang digunakan $20 \times 20 \mathrm{~cm}$. Penanaman padi dilakukan sebelum ikan ditebar. Pada saat penanaman ketinggian air dipetakan sawah $4-5 \mathrm{~cm}$. Benih ikan ditebar pada sore hari saat keadaan suhu air rendah (dingin). Jumlah penebaran benih ikan pada perlakuan P1 adalah 22 ekor, P2 yaitu 33 ekor/petak dan pada perlakuan P3 44 ekor (Anonim, 2016).

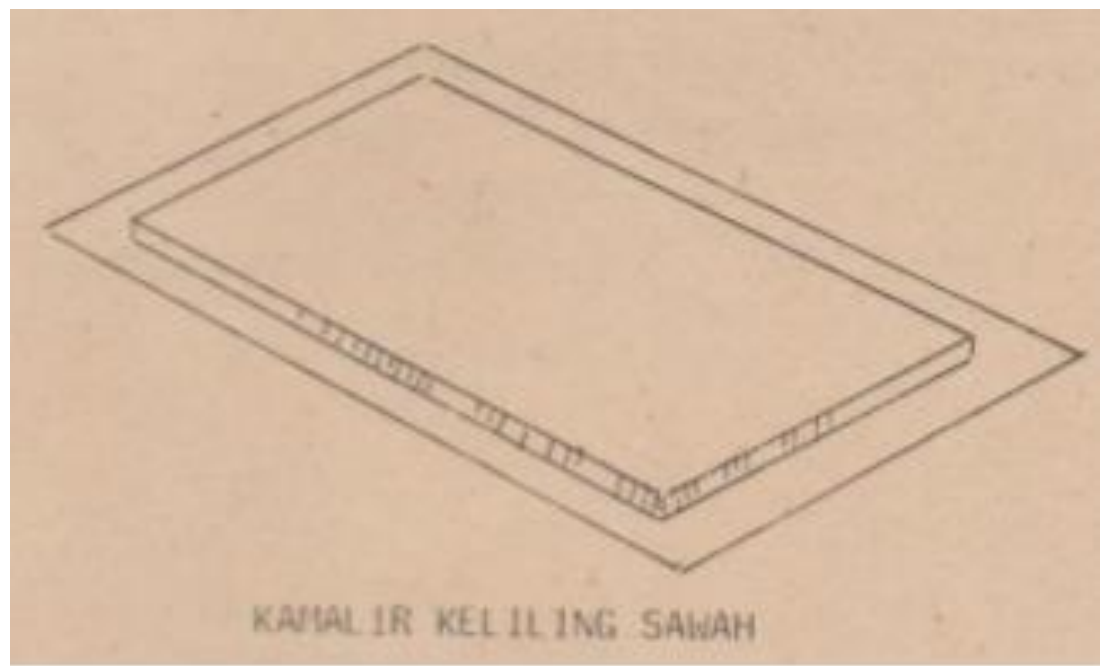

Gambar 1. Tampak petak sawah mina padi

Pengaturan air pada masa pemeliharaan pertama tinggi air dalam petakan $5 \mathrm{~cm}$ dan dinaikan secara bertahap sampai ketinggian $10 \mathrm{~cm}$ yang pada tahap selanjutnya ketinggian air dapat ditingkatkan menjadi $10-20 \mathrm{~cm}$. Cara pemberian makanan dengan ditebar. Pemberian makan dilakukan 2 (dua) kali sehari, yaitu pagi (pukul 08.00) dan sore (pukul 17.00) (Tahir dan Pasaribu, 2002). Jumlah makanan yang diberikan adalah P1 sebanyak 8 gram/hari, P2 sebanyak 12 gram/hari, dan P3 sebanyak 16 gram/hari. (Anonim, 1991). 
Analisis tanah sebelum perlakuan dilakukan dengan mengambil sampel tanah sawah 2 hari setelah lahan diolah dan dialiri air. Sampel diambil pada setiap petak percobaan kemudian dikompositkan. Sedangkan untuk analisis setelah perlakuan meliputi analisis tanah, tanaman, dan ikan yang dilakukan dengan mengambil sampel tanah sawah, tanaman, dan ikan pada umur padi \pm 70 hst atau saat padi pada fase vegetative maksimal. Parameter tanah yang diamati yaitu: $\mathrm{pH} \mathrm{H}_{2} \mathrm{O}$ dengan menggunakan $\mathrm{pH}$ meter, Eh dengan menggunakan Eh meter, $\mathrm{Mn}$ terlarut dengan pengekstrak $\mathrm{NH}_{4} \mathrm{OAc}$ pH 4,8, Fe terlarut dengan pengekstrak $\mathrm{NH}_{4}$ ASETAT pH 4,8, C-organik dengan metode Walkley \& Black, $\mathrm{N}$ tersedia dengan pengekstrak $\mathrm{KCl}, \mathrm{P}$ tersedia dengan metode Bray, $\mathrm{K}$ tersedia dengan pengekstrak $\mathrm{NH}_{4} \mathrm{OAc}$ (Afany, 1999). Parameter tanaman yang diamati yaitu: yinggi tanaman, jumlah anakan, berat segar, berat kering. Parameter ikan yang diamati yaitu: berat segar ikan/petak, dan berat segar ikan/ekor. Untuk mengetahui pengaruh perlakuan dilakukan analisis data dengan sidik ragam (ANOVA) dan untuk mengetahui perbandingan antara perlakuan menggunakan Duncan Multiple Range Test (DMRT) pada taraf 5\%.

\section{HASIL DAN PEMBAHASAN}

Tabel 1. Hasil analisis sifat kimia tanah sebelum perlakuan

\begin{tabular}{clcc}
\hline No & \multicolumn{1}{c}{ Parameter } & Nilai & Harkat \\
\hline 1 & pH & & Sedang \\
& a. $\quad \mathrm{H}_{2} \mathrm{O}$ & 6,4 & Rendah \\
& b. $\quad \mathrm{KCl}$ & 5,2 & Reduksi rendah \\
2 & Potensial redoks (mV)* & 161 & Rendah \\
3 & C - Organik (\%) & 4,06 & Rendah \\
4 & N Tersedia (\%) & 0,039 & Rendah \\
5 & P Tersedia (ppm) & 5,516 & Sedang \\
6 & K Tersedia (me \%) & 0,513 & Diatas nilai Defisiensi \\
7 & Fe (ppm) & 22,453 & Diatas nilai Defisiensi \\
8 & Mn (ppm) & 122,686 &
\end{tabular}

Tabel 1 menunjukkan bahwa terdapat kendala kesuburan kimiawi Regosol diantaranya reaksi tanah $\left(\mathrm{pH} \mathrm{H}_{2} \mathrm{O}\right)$ berkisar 6,4 yang mempunyai harkat sedang. $\mathrm{C}$ organik sebesar 4,06\% yang termasuk berharkat rendah. Nilai $\mathrm{N}$ tersedia sebesar $0,0392 \%$ yang termasuk dalam harkat rendah, $\mathrm{P}$ tersedia sebesar 5,516 ppm yang termasuk berharkat rendah, $\mathrm{K}$ tersedia 0,5131 me $\%$ yang berharkat sedang, nilai $\mathrm{Fe}$ sebesar 22,453 ppm yang termasuk diatas nilai defisiensi dan Mn sebesar 122,6868 ppm yang jauh diatas nilai defisiensi. Pengharkatan kimiawi tanah tersebut menurut Landon, (1984). Sedangkan nilai potensial redoks (Eh) sebesar 161 menurut pengharkatan Liu, (1985) dalam Syakhfani, (2014) termasuk dalam keadaan reduksi rendah. Hal ini dapat disebabkan karena keadaan tanah yang diambil untuk analisis pendahuluan ini merupakan yang yang pada masa awal penggenangan. Reaksi redoks terjadi pada hampir semua tanah. Biasanya, reaksi oksidasi berkaitan dengan kondisi tanah berdrainase baik, sedangkan proses reduksi berkaitan dengan kondisi tanah berdrainase buruk atau apabila terdapat air berlebih (Surachman, 2010). Kondisi reduktif pada tanah ini yang mengakibatkan nilai $\mathrm{Fe}$ dan $\mathrm{Mn}$ pada tanah menjadi tersedia. Perubahan bentuk $\mathrm{Fe}^{+3}$ 
menjadi $\mathrm{Fe}^{+2}$ terjadi karena adanya perubahan suasana oksidatif menjadi reduktif (Yoshida, 1981., dalam Ciyo 2008). Dalam suasana reduksi, misalnya tanah dikelola secara sawah (digenangi), maka Mn (IV) dan Mn (III) akan direduksi menjadi Mn (II) yang relative lebih mudah larut (Ponnemperuma,1997 dalam Rosmarkam dan Yuwono, 2002).

Tabel 2. Hasil analisis pakan ikan Hi Pro Vite 771

\begin{tabular}{llc}
\hline No & \multicolumn{1}{c}{ Parameter } & Nilai \\
\hline 1. & pH $\mathrm{H}_{2} \mathrm{O}$ & 5,7 \\
2. & $\mathrm{C}-$ Organik $(\%)$ & 50,74 \\
3. & N Total $(\%)$ & 4,14 \\
4. & P Total (\%) & 4,47 \\
5. & K Total $(\%)$ & 1,19 \\
\hline
\end{tabular}

Dari tabel 2 diketahui analisis pakan ikan menunjukkan bahwa pakan ikan memiliki nilai $\mathrm{C}$ organik sebesar 50,74 \%, kandungan $\mathrm{N}$ total sebesar $4,14 \%$, kandungan $\mathrm{P}$ total $4,47 \%$, dan kandungan $\mathrm{K}$ total sebesar $1,19 \%$. Nilai $\mathrm{C}$ organik dan $\mathrm{N}$ total ini telah disetarakan dengan kandungan protein kasar sebesar 25,9 \%, kandungan lemak kasar 6,1 $\%$, dan serat kasar sebesar 5,8\% (Usman et al., 2010).

\section{Analisis Tanah Setelah Perlakuan}

Tabel 3. Hasil analisis sifat kimia tanah setelah perlakuan

\begin{tabular}{|c|c|c|c|c|c|c|c|c|}
\hline Perlakuan & $\mathbf{p H ~ H _ { 2 }} \mathbf{O}$ & Eh $(\mathbf{m V})$ & $\begin{array}{c}\mathrm{C}- \\
\text { Organik } \\
(\%)\end{array}$ & $\begin{array}{c}\mathbf{N} \\
\text { Tersedia } \\
(\%)\end{array}$ & $\begin{array}{c}\mathbf{P} \\
\text { Tersedia } \\
(\mathbf{p p m})\end{array}$ & $\begin{array}{c}\mathbf{K} \\
\text { Tersedia } \\
\text { (me \%) }\end{array}$ & $\begin{array}{c}\mathrm{Fe}^{2+} \\
(\mathbf{p p m})\end{array}$ & $\begin{array}{c}\mathbf{M n}^{2+} \\
(\mathbf{p p m})\end{array}$ \\
\hline Po & $6,2 \mathrm{a}$ & $156,75 \mathrm{a}$ & $\begin{array}{c}4,508 \\
\mathrm{a}\end{array}$ & $\begin{array}{c}0,0542 \\
\mathrm{a}\end{array}$ & $\begin{array}{c}3,724 \\
\mathrm{a}\end{array}$ & $0,8666 \mathrm{a}$ & $\begin{array}{c}111,93 \\
\mathrm{a}\end{array}$ & $\begin{array}{c}541,23 \\
\mathrm{a}\end{array}$ \\
\hline P1 & $\begin{array}{c}6,175 \\
a\end{array}$ & $154,25 \mathrm{a}$ & $\begin{array}{c}4,648 \\
a\end{array}$ & $\begin{array}{c}0,0675 \\
\mathrm{a}\end{array}$ & $\begin{array}{c}3,962 \\
\mathrm{a}\end{array}$ & $0,9120 \mathrm{a}$ & $\begin{array}{c}118,29 \\
\mathrm{a}\end{array}$ & $\begin{array}{c}541,84 \\
\mathrm{a}\end{array}$ \\
\hline $\mathbf{P 2}$ & $6,1 \mathrm{a}$ & $153 \mathrm{a}$ & $\begin{array}{c}6,328 \\
a\end{array}$ & $\begin{array}{c}0,1047 \\
\mathrm{a}\end{array}$ & $\begin{array}{c}4,452 \\
\mathrm{a}\end{array}$ & $0,9464 \mathrm{a}$ & $\begin{array}{c}102,73 \\
\mathrm{a}\end{array}$ & $\begin{array}{c}556,85 \\
\mathrm{a}\end{array}$ \\
\hline P3 & $\begin{array}{c}6,025 \\
a\end{array}$ & $149,25 \mathrm{a}$ & $\begin{array}{c}6,705 \\
\mathrm{a}\end{array}$ & $\begin{array}{c}0,0657 \\
\mathrm{a}\end{array}$ & $\begin{array}{c}3,909 \\
\mathrm{a}\end{array}$ & $0,8577 \mathrm{a}$ & $\begin{array}{c}126,88 \\
\mathrm{a}\end{array}$ & $\begin{array}{c}633,07 \\
\mathrm{a}\end{array}$ \\
\hline
\end{tabular}

Keterangan: Angka yang diikuti oleh huruf yang sama tidak menunjukkan beda nyata, berdasarkan sidik ragam (ANOVA) taraf $5 \%$.

\section{1. $\mathrm{pH} \mathrm{H}_{2} \mathrm{O}$}

Dari tabel $3 \mathrm{P} 0$ memiliki $\mathrm{pH} \mathrm{H}_{2} \mathrm{O}$ lebih tinggi namun tidak berbeda nyata dari P1, P2, dan P3. Menurut Nugroho et al. (2012) dalam penelitiannya mengemukanan bahwa $\mathrm{pH}$ air dalam media akuaponik lebih rendah dibandingkan media nonakuaponik, meskipun hasil perhitungan analisis ragam menunjukkan bahwa penggunaan sistem akuaponik pada level 5\% tidak berpengaruh secara nyata terhadap kondisi $\mathrm{pH}$ air media budidaya. Ini dapat disebabkan karena bahan organik masih dalam keadaan mentah. Dalam proses dekomposisi bahan organik akan menghasilkan asam asam organik sehingga menyebabkan $\mathrm{pH}$ turun (Rosmarkan dan Yuwono, 2002). Ini sesuai dengan kandungan $\mathrm{C}$ organik pada tanah. 


\section{Eh}

Dari Tabel 3 dapat diketahui bahwa P0 memiliki nilai Eh lebih tinggi namun tidak berbeda nyata dari P1, P2, dan P3. Hal tersebut disebabkan oleh aktivitas mikroorganisme yang bekerja dalam proses dekomposisi bahan organik. Mikroorganisme tanah menggunakan bagian oksidatif tanah untuk menggantikan peran oksigen sebagai aseptor elektron pada proses respirasi mikroorganisme, sehingga membentuk kondisi reduktif pada tanah (De Datta, 1981 dalam Surachman, 2010). Ini sesuai dengan hasil analisis $C$ organik pada tanah. Penurunan nilai Eh tanah juga terlihat jika dibandingkan dengan sebelum perlakuan (Tabel 1). Menurut Reddy dan Patrick, Jr (1986) dalam Ciyo (2008) Proses penggenangan akan menyebabkan terjadinya deplesi $\mathrm{O}_{2}$, dan penurunan tersebut akan diikuti oleh penurunan Eh. Semakin lama suatu tanah tergenang semakin tinggi deplesi $\mathrm{O}_{2}$ dan semakin menurun pula Eh tanah, bahkan bisa sampai pada nilai Eh $-350 \mathrm{mV}$.

\section{C-Organik}

Dari Tabel 3 dapat diketahui bahwa P3 memiliki C - organik lebih tinggi namun tidak berbeda nyata dari P0, P1, dan P2. Sumber C - organik pada penelitian ini bersumber dari kotoran ikan, sisa pakan, serta dari tanaman - tanaman disekitar penelitian yang masuk dan terambil saat pengambilan sampel. Umumnya, bahan organik yang tersedia dan dimanfaatkan diantaranya ialah residu tanaman atau bahan hijauan tanaman (Yulnafatmawita et al., 2010 dalam Sismiyati et al., 2018).

\section{4. $\quad$ T Tersedia}

Dari Tabel 3 dapat diketahui bahwa P2 memiliki $\mathrm{N}$ tersedia lebih tinggi namun tidak berbeda nyata dari P0, P1, dan P3. Hasil yang tidak bedanyata dapat terjadi karena hara yang diberikan telah diserap oleh tanaman, sehingga yang tersisa di tanah hanya residu hara yang tidak diserap oleh tanaman. Sistem mina padi mulai optimal pada P2. Penurunan kadar N pada P3 ini dapat disebabkan karena pada P3 dimungkinkan memiliki kadar $\mathrm{NH}_{3}$ hasil pembongkaran bahan organik di dalam air terdapat dalam jumlah besar, yang disebabkan proses pembongkaran protein terhenti sehingga tidak terbentuk nitrat sebagai hasil akhir, maka air tersebut disebut "sedang mengalami pengotoran (Pollution)" (Metcalf dan Eddy, 1991 dalam Nugroho, 2012).

\section{P Tersedia}

Dari Tabel 3 dapat diketahui bahwa P2 memiliki P tersedia lebih tinggi namun tidak berbeda nyata dari P0, P1, dan P3. Hasil pengamatan P tersedia semakin meningkat dengan adanya penambahan bahan organik (Ciyo, 2012). Bahan organik yang tersebut ialah bahan organik yang berasal dari kotoran ikan. Pada P3 mengalami penurunan akibat pertumbuhan ikan tidak maksimum atau optimum pada P2 (Tabel 5), sehingga produksi kotoran pada P2 juga lebih besar.

\section{K Tersedia}

Dari Tabel 3 dapat diketahui bahwa P2 memiliki K tersedia lebih tinggi namun tidak berbeda nyata dari P0, P1, dan P3. Ini dapat diterjadi karena bahan organik yang berasal dari kotoran ikan. Pada P3 mengalami penurunan akibat pertumbuhan ikan tidak maksimum atau optimum pada P2 (tabel 5), sehingga produksi kotoran pada P2 juga lebih besar. Kalium tersedia dalam tanah tidak selalu tetap dalam keaadaan tersedia, tetapi masih berubah menjadi bentuk yang lambat untuk diserap oleh 
tanaman (slowly available). Hal ini disebabkan oleh $\mathrm{K}$ tersedia yang mengadakan keseimbangan dengan K bentuk - bentuk lain (Rosmarkam dan Yuwono, 2002)

\section{7. $\mathrm{Fe}^{2+}$}

Dari Tabel 3 dapat diketahui bahwa P3 memiliki Fe lebih tinggi namun tidak berbeda nyata dari P0, P1, dan P2. Ini dapat dikarenakan bahan organik tanah dapat mengikat besi. Asam-asam organik, sidepora, dan flavonoid mengikat besi dan menjadikan besi tersedia bagi tanaman (Colombo et al.., 2014 dalam Gelyaman, 2018). Namun pada P2 nilai Fe justru turun. Ini dapat disebabkan karena dapat dimungkinkan sebagian hara Fe2+ pada P2 telah diserap dan dimanfaatkan oleh tanaman lebih banyak.

\section{8. $\mathrm{Mn}^{2+}$}

Dari Tabel 3 dapat diketahui bahwa P3 memiliki Mn lebih tinggi namun tidak berbeda nyata dari P0, P1, dan P2. Ini dapat terjadi karena pada reaksi tanah masam, unsur - unsur mikro juga menjadi mudah larut, sehingga ditemukan unsur mikro terlalu banyak. Termasuk unsur mikro dalam jenis ini adalah $\mathrm{Fe}, \mathrm{Mn}, \mathrm{Zn}, \mathrm{Cu}, \mathrm{Co}$ (Hardjowigeno, 2010).

\section{Analisis Pertumbuhan Tanaman}

Tabel 4. Hasil analisis pertumbuhan tanaman

\begin{tabular}{ccccc}
\hline Perlakuan & $\begin{array}{c}\text { Tinggi } \\
\text { Tanaman (cm) }\end{array}$ & Jumlah Anakan & $\begin{array}{c}\text { Berat Segar } \\
\text { (gram) }\end{array}$ & $\begin{array}{c}\text { Berat Kering } \\
\text { (gram) }\end{array}$ \\
\hline P0 & $88,04 \mathrm{a}$ & $8 \mathrm{a}$ & $47,67 \mathrm{a}$ & $14,58 \mathrm{a}$ \\
P1 & $98,99 \mathrm{~b}$ & $11 \mathrm{~b}$ & $71,255 \mathrm{ab}$ & $21,915 \mathrm{ab}$ \\
P2 & $106,635 \mathrm{~b}$ & $12 \mathrm{~b}$ & $93,625 \mathrm{~b}$ & $24,235 \mathrm{~b}$ \\
P3 & $98,06 \mathrm{~b}$ & $10 \mathrm{ab}$ & $62,325 \mathrm{a}$ & $15,46 \mathrm{a}$ \\
\hline
\end{tabular}

Keterangan: Angka yang diikuti oleh huruf yang sama tidak menunjukkan beda nyata, berdasarkan uji DMRT taraf 5\%.

\section{Tinggi Tanaman}

Dari Tabel 4 dapat diketahui bahwa P2 memiliki tinggi tanaman lebih tinggi berbeda nyata dari P0, namun tidak berbeda nyata dari P1, dan P3. Pertumbuhan vegetatif tanaman seperti tinggi tanaman sangat dipengaruhi oleh unsur nitrogen $(\mathrm{N})$. Fungsi $\mathrm{N}$ ialah memperbaiki pertumbuhan vegetatif tanaman. Tanaman yang tumbuh pada tanah yang cukup N, berwarna lebih hijau (Harjowigeno, 2010). Peranan nitrogen secara khusus pada tanaman adalah berperan dalam: pertumbuhan vegetatif tanaman, memberikan warna pada tanaman, panjang umur tanaman, penggunaan karbohidrat, dan lain-lain (Zailani, Kadir, et al., 1993 dalam Nugroho et al., 2012). Ini sesuai dengan ketersediaan hara N (Tabel 3).

\section{Jumlah Anakan}

Dari Tabel 4 dapat diketahui bahwa P2 memiliki jumlah anakan lebih tinggi berbeda nyata dari P0, namun tidak berbeda nyata dari P1, dan P3. Pertumbuhan vegetatif tanaman seperti jumlah anakan juga sangat dipengaruhi oleh unsur nitrogen (N). Fungsi $\mathrm{N}$ ialah memperbaiki pertumbuhan vegetatif tanaman (Harjowigeno, 2010). Ini sesuai dengan ketersediaan hara N (Tabel 3). 


\section{Berat Segar dan Berat Kering Tanaman}

Dari Tabel 4 dapat diketahui bahwa P2 memiliki berat segar dan berat kering lebih tinggi berbeda nyata dari P0, dan P1, namun tidak berbeda nyata dari P3. Ini menunjukkan berat segar total berbanding lurus dengan berat kering total. Berat kering total tanaman adalah parameter yang digunakan untuk mengetahui pertumbuhan bibit, karena merupakan gambaran efisiensi dari proses fisiologis di dalam tanaman (Wulandari dan Susanti, 2012). Seperti pada pernyataan Harjadi (2007) dalam Wijiyanti et al., (2019) mengatakan bahwa ketersediaan unsur hara berperan penting sebagai sumber energi sehingga tingkat kecukupan hara berperan dalam mempengaruhi biomassa dari suatu tanaman. Sesuai dengan (Tabel 3) hara optimum terdapat pada perlakuan P2. Berat segar dan berat kering tanaman juga dipengaruhi oleh tinggi tanaman serta jumlah anakan (Tabel 4). Semakin tinggi dan banyak jumlah anakan maka berat bsah dan berat kering tanaman juga akan semakin tinggi.

Tabel 5. Hasil analisis pertumbuhan ikan

\begin{tabular}{ccc}
\hline Perlakuan & Berat Segar Ikan/Petak (gram) & Berat Segar Ikan/Ekor (gram) \\
\hline P0 & $0 \mathrm{a}$ & $0 \mathrm{a}$ \\
P1 & $579,35 \mathrm{~b}$ & $26,334 \mathrm{c}$ \\
P2 & $847,7 \mathrm{c}$ & $25,688 \mathrm{c}$ \\
P3 & $696,3 \mathrm{bc}$ & $15,825 \mathrm{~b}$ \\
\hline
\end{tabular}

Keterangan: Angka yang diikuti oleh huruf yang sama tidak menunjukkan beda nyata, berdasarkan uji DMRT taraf 5\%.

\section{Berat Segar Ikan}

Dari Tabel 5 dapat diketahui bahwa P2 memiliki hasil berat segar ikan/petak lebih tinggi berbeda nyata dari P0, P1, namun tidak berbeda nyata dari P3. Hal ini menunjukkan bahwa hasil produksi optimal terdapat pada perlakuan P2, sesuai dengan penelitian Sudiarta et al. (2016) yang menyatakan perlakuan kepadatan populasi ikan nila bobot hasil tertinggi pada perlakuan 24 ekor/petak sebesar $(242.25$ gr) pada padat penebaran 5-8 ekor/meter ${ }^{2}$ dengan berat ikan 3-5 gram/ekor. Dari tabel juga dapat diketahui bahwa P1 memiliki hasil berat segar ikan/ekor lebih tinggi berbeda nyata dari P0, P3, namun tidak berbeda nyata dari P2. Hal ini sesuai dengan pendapat Resmiaty dan Mayunar (1990) dalam Tahir dan Pasaribu (2003) bahwa ikan akan tumbuh dengan baik pada ruang gerak yang lebar. Dilihat dari berat segar ikan/ekor dan berat segar ikan/petak hasil terbaik ditunjukkan pada perlakuan mina padi dengan kepadatan ikan 22 ekor/petak dengan produksi 847,7 gram dan berat ikan/ekor 25,688 gram.

\section{KESIMPULAN}

Berdasarkan hasil penelitian mengenai pengaruh populasi ikan terhadap ketersediaan hara tanah pada sistem mina padi dapat ditarik kesimpulan sebagai berikut:

1. Jumlah populasi ikan pada sistem mina padi sawah tidak berpengaruh nyata dalam meningkatkan sifat kimia tanah dan ketersediaan hara tanah. khususnya pada $\mathrm{pH}, \mathrm{Eh}$, $\mathrm{C}$ - organik, $\mathrm{N}$ tersedia, $\mathrm{P}$ tersedia, $\mathrm{K}$ tersedia, Fe, dan Mn. 
2. Jumlah populasi ikan pada sistem mina padi sawah berpengaruh nyata dalam meningkatkan pertumbuhan padi sawah varietas rojo lele khususnya pada tinggi tanaman, jumlah anakan, berat segar, dan berat kering tanaman.

3. Ketersediaan hara, pertumbuhan padi, dan pertumbuhan ikan paling baik ditunjukkan pada perlakuan sawah mina padi dengan kepadatan ikan 33 ekor/petak

\section{DAFTAR PUSTAKA}

Afany, M.R., 1999. Analisa Kimiawi Tanah Prinsip Kerja dan Intersepinya. Jurusan Ilmu Tanah Fakultas Pertanian Universitas Pembangunan Nasional "Veteran" Yogyakarta. Yogyakarta.

Anonim, 1991., Mina Padi di Sawah Pasang Surut. Departemen Pertanian Balai Informasi Pertanian. Kalimantan Tengah.

Anonim, 2016. Petunjuk Teknis Sarana Budidaya Padi. Kementrian Kelautan dan Perikanan Republik Indonesia. Jakarta.

Ciyo, M.B., 2008. Efektivitas Bahan Organik Dan Tinggi Genangan Terhadap Perubahan Eh, Ph, Dan Status Fe, P, Al Terlarut Pada Tanah Ultisol. J. Agroland 15 (4): 257 - 263, Desember 2008. ISSN : 0854 - 641X. Palu.

Gelyaman, G.D., 2018. Faktor - Faktor Yang Mempengaruhi Bioavailabilitas Besi Bagi Tumbuhan. Portal Jurnal Unimor. Jurnal Saintek Lahan Kering (2018) ISSN 26221020. Kefamenanu

Harjowigeno, S., 2010. Ilmu Tanah. Akademika Pressindo. Jakarta.

Landon, 1984. Booker Tropical Soil Manual. Longman Inc. New York.

Nugroho, R.A., L.T. Pambudi ., D. Chilmawati., dan A.H.C. Haditomo. 2012. Aplikasi Teknologi Aquaponic pada Budidaya Ikan Air Tawar Untuk Optimalisasi Kapasitas Produksi. Jurnal Saintek Perikanan Vol. 8. No. 1, 2012. Semarang.

Rosmarkam, A., N.W. Yuwono. 2002. Ilmu Kesuburan Tanah. PT Kanisius. Yogyakarta.

Sismiyati., Hermansah., Yulnafatmawita. 2018. Klasifikasi Beberapa Sumber Bahan Orgaik dan Optimalisasi Pemanfaatannya Sebagai Biochar. Jurnal Solum ISSN 2356-0835: 8-16. Padang.

Sudiarta, I.M., E. Syam'un.,R Syamsudin. 2016. Pertumbuhan dan Produksi Tanaman Padi Serta Produksi Ikan Nila Padi Sistem Tanam Jajar Legowo. J. Sain \& Teknologi, April 2016, Vol.16 No.1 : 70-80. Makasar.

Surachman, D. 2010. Potensial Redoks (Eh) dan Kelarutan Fe dan Mn Serta Kaitannya dengan Pertumbuhan Padi pada Budidaya Sistem Konvensional dan System Of Rice Intensification. Skripsi Departemen Ilmu Tanah Dan Sumberdaya Lahan Fakultas Pertanian Institut Pertanian Bogor. Bogor.

Syekhfani. 2014. Potensi Oksidasi-Reduksi. Bahan Ajar. Pascasarjana Fakultas Pertanian Universitas Brawijaya. Malang.

Tahir, A.G., A.M. Pasaribu. 2003. Kajian Adaptasi Udang Galah (Macrobrachium rosenbergii) Dan Ikan Mas (Cyprinus carpio) Dengan Sistem Mina Padi Jajar Legowo Di Lahan Sawah Irigasi. Jurnal Pengkajian Dan Pengembangan Teknologi Pertanian Vol. 6, No. 2, Juli 2003 : 167-175. Ujung Pandang.

Usman ., N.N. Palinggi., E. Harris., D. Jusadi., E. Supriyono., M Yuhana. 2010. Analisis Tingkat Kecernaan Pakan dan Limbah Nitrogen (N) Budidaya Ikan Bandeng Serta Kebutuhan Penambahan C - Organik untuk Penumbuhan Bakteri Heterotrof (Bioflog). J. Ris. Akuakultur Vol.5 No.3 Tahun 2010: 481-490. Bogor. 
Wijiyanti, P., E.D. Hastuti., S. Haryanti., 2019. Pengaruh Masa Inkubasi Pupuk dari Air Cucian Beras Terhadap Pertumbuhan Tanaman Sawi Hijau (Brassica juncea L.). Buletin Anatomi dan Fisiologi Volume 4 Nomor 1 Februari 2019 . p-ISSN 25276751. Semarang

Wulandari, A.S. dan Susanti, S. 2012. Aplikasi Pupuk Daun Organik untuk Meningkatkan Pertumbuhan Bibit Jabon (Anthocephalus cadamba Roxb. Miq.). Jurnal Silvikultur Tropika. 3(2) : 137 - 142 Yusra. 200. Bogor 